\title{
マイクロスフェア肺塞栓による慢性肺高血圧モデルの 作成および血清中エンドセリン濃度の変化
}

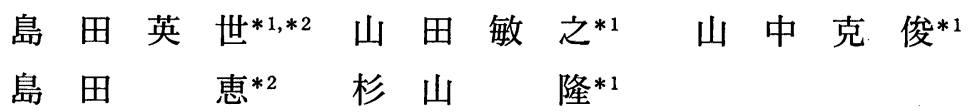

[目的 ]

臨床において肺塞栓症に合併した肺高血圧はし ばしば右心不全をきたし、予後の重要な規定因 子となる。動物実験ではガラスビーズなどでの 急性肺塞栓症モデルでの検討' ${ }^{1}$ が行われている が、肺血管床は潜在的部分が多く単回の塞栓形 成では十分な肺動脈圧の充進はきたさない。そ こで我々は家兔で非放射性カラードマイクロス フェア(以下MS)を反復投与し、肺塞栓症による 慢性肺高血圧モデルの作成を試みた。また血中 や尿中のエンドセリン-1(以下ET-1)濃度が、ヒ 卜の肺塞栓症 ${ }^{2}$ や他の肺高血圧症モデル ${ }^{3)}$ で上昇 することが報告されていることから、肺高血圧 の指標として血清中ET-1濃度の測定を行った。

\section{[ 実験材料および方法 ]}

実験動物として日本白色雄性家鬼を用いた。急 性実験として耳静脈より直径 $50 \mu \mathrm{m}$ のMSを 10,20,40万個それぞれ投与し、血行動態の変化 を、投与前、投与 1 分後、 5 分後、 10 分後、 15 分後および 30 分後において記録した。

その結果、10万個のMS投与では、右室収縮期 圧の上昇はほとんど見られなかった。20万個の MS投与では、投与 10 分後にピークを持つ上昇 をきたしたが、その上昇は持続せず、30分後に はほほ正常値まで回復した。一方、40万個の MS投与では、5分後にピークを持つ上昇をきた し、その上昇は 30 分後も持続していた。これら

*1 北里大学薬学部臨床薬学研究センター病態解析部門 干 108-8641 東京都港区白金 5-9-1

*2 北里研究所病院内科
の結果より、MS 1 回の投与量を40万個とした。 慢性実験として耳介静脈よりMS 40万個/d a y 5 日間連続投与し(MS群, $n=5$ ) 投与終了7日後、 u reth an e $(450 \mathrm{mg} / \mathrm{kg})$ および $\alpha$-chloralose ( $45 \mathrm{mg} / \mathrm{kg})$ による麻酔下において、挿管し、レ スピレーターに接続後、開胸し血行動態の測定 を行った。血行動態の測定後、採血し遠心分離 後に血清として保存し、ET-1測定用とした。 対照群では生理食塩液 $2 \mathrm{ml} / \mathrm{d}$ ay を同様に投与し (vehicle群, $\mathrm{n}=5$ )、同様の検討を行った。

(1)生理学的観察

大動脈圧波形および右室圧波形より、心拍数、 平均大動脈圧および右室収縮期圧を算出した。

(2)MSの分布および肺塞栓の観察

麻酔により屠殺後、両肺を摘出し、凍結切片を 作成した。一部の家兔では肺の他に肝臓、腎臓 を摘出し、各葴器でのMSの抽出を行い、白血 球計数板でMSの計数を行った。

(3)血清中ET-1 濃度の測定

血清中 ET- 1 濃度の测定は、ET測定キット( BIOMEDICA, BI-20052)を用いて行った。

(4)病理組織学的観察

肺については 1 個体の各小葉について 1 枚、合 計 5 枚の厚さ2 3 $3 \mu \mathrm{m}$ のパラフィン切片を作成 し、弾性絨維染色法であるエラスチカ・ワン ギーソン染色により染色し、病理組織標本を作 成した。各々の標本から51 100、101 200お よび201 400 $\mu \mathrm{m}$ の肺動脈を 2 本ずつ、すなわ ち、各個体あたり10本の肺動脈を無作為的に選 び、その外径および中膜の厚さを測定した。そ の結果から各肺動脈の中膜肥厚度 $(\%)=$ [ (中膜 の厚さ $\times 2$ )/外径 $\times 100$ ]を算出した。 
(A) 右室収缩期圧

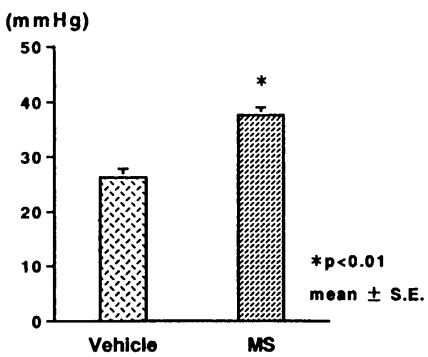

(B) 血清中ET-1濃度

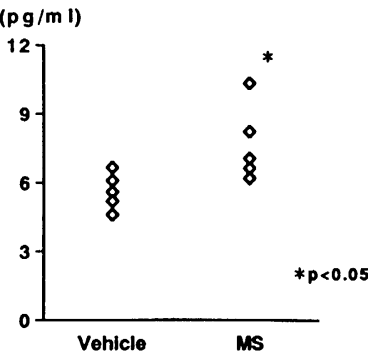

(C) 肺動脈中膜肥厚度

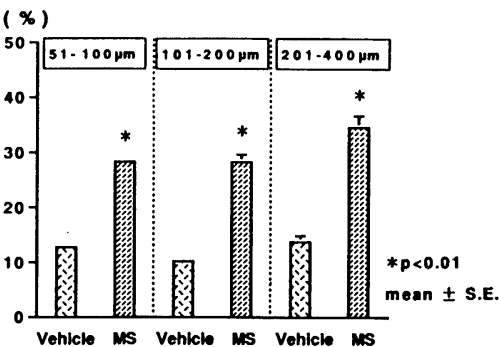

Fig. 1 MS投与による右室収缩期圧、血清中ET-1 䈨度およひ肺動䛲中膜肥厚度の变化

\section{[ 結果 ]}

(1)心拍数および平均大動脈圧は両群において差 は認められなかったが、右室収縮期圧はMS群 において有意に上昇し、肺高血圧が示唆された (Fig. 1-A)。

(2)MS肺塞栓は凍結切片によりMSと同程度の大 きさの肺動脈に確認され、抽出により肺にのみ 全量が取り込まれていることが確認された。

(3)血清中ET-1 濃度は、MS群において有意に上 昇した(Fig. 1-B)。

(4)肺動脈中膜肥厚度の変化は、MS群において 有意に上昇し、肺動脈中膜の肥厚が見られた( Fig. 1-C )。

\section{[ 結論 ]}

MS肺塞栓による本実験系が、慢性肺高血圧モ デルとして有用である。

\section{[ 文献 ]}

1) 高杉知明,山口佳寿博,河合章 他, 日胸疾会 誌, 31 :1114-1119, 1993.

2) Matteo, S., Stan islao, F., Marco, A., et al., Chest, $111: 544-549,1997$.

3)Miyauchi, T., Yorikane, R., Sakai, S., et al., Circ. Res., 73:887-897, 1993. 